\title{
Challenges and Solutions for Integrating and Financing Personalized Medicine in Healthcare Systems: A Systematic Literature Review
}

\author{
Veronika Kalouguina ${ }^{1,+}$ and Joël Wagner ${ }^{1,2, *,+}$ \\ 1 Department of Actuarial Science, Faculty HEC, University of Lausanne, Extranef, \\ 1015 Lausanne, Switzerland; veronika.kalouguina@unil.ch \\ 2 Swiss Finance Institute, University of Lausanne, 1015 Lausanne, Switzerland \\ * Correspondence: joel.wagner@unil.ch \\ $\dagger$ These authors contributed equally to this work.
}

Received: 15 October 2020; Accepted: 13 November 2020; Published: 16 November 2020

\begin{abstract}
The scope and ambitions of biomedical institutions worldwide currently working toward the integration of personalized medicine (PM) require recognizing the potential profound impact on regulatory standards and on the economic functioning and financing of healthcare. Against this background, researchers and policymakers must manage the arising challenges for the healthcare systems. In this paper we study the literature related to the consequences of PM on health insurance and care systems. Using the PRISMA research protocol, we search the existing body of literature and analyze publications dealing with insurance (419 papers) in the field of PM. After a detailed reading of the 52 studies included in our analysis, we synthesize challenges in three fields that must be addressed to avoid hindering the implantation of PM. The key issues that we highlight concern (1) a lack of clear and consistent data on the economic relevance of PM, (2) a value-oriented and cost-efficient definition of reimbursement thresholds, (3) the implementation of PM in the prevailing healthcare system. In the meantime, we provide several solutions to these concerns; we present (a) risk-sharing contracts that can deal with the emerging coverage challenges, (b) criteria that could constitute future reimbursement thresholds and (c) examples of successful implementations of PM into healthcare systems. Our findings are relevant for policymakers and health insurance companies for redefining the guidelines for the healthcare schemes of the future.
\end{abstract}

Keywords: personalized medicine; health insurance; financial management; genetics

\section{Introduction}

Personalized, stratified, precision or genomic medicine bear the same logic: a particular problem requires a tailored solution, i.e., a specific genetic mutation leading to a health condition should be treated with a specific drug. The often costly trial-to-error paradigm leading to adverse drug responses (Spear et al. 2001; Sultana et al. 2013) is being slowly replaced by a data-based optimization of resources that we refer to with personalized medicine (PM). In the prevailing procedures, the time, health and energy wasted as well by doctors as by patients in an iterative search of the best drug response translates into expenses paid by the sponsors, i.e., insurers, governments or private payers. Fast forward twenty years, with PM, before a patient starts his/her course of treatment, we determine which drug will lead to the best outcome and minimize the risks of adverse events. Doctors have access to the necessary medical data of the patient on the spot with the implementation of electronic health records (Henry et al. 2016). Individuals have the possibility of having their DNA sequenced to draw a risk profile for the most common afflictions as well as personal at-risk conditions (Hammond 2020). 
Finally, combining all the flows of health-related data (such as information collected from wearable devices) with gene mutations, research hubs gain a more precise and accurate knowledge, which is clinically applied. Going back to the present, we already have the technology for a fast, cheap and accurate DNA sequencing. For instance, next generation sequencing technology (NGS) has replaced the Sanger method, resulting in the cost of a whole genome sequencing drastically decreased with a cutback in prices by two hundred times in only ten years, decreasing from roughly USD 200,000 in 2009 to less than USD 1000 in May 2020 (National Human Genome Research Institute 2020). Smart wearable devices are continuously collecting data (Dunn et al. 2018) laying the ground for a common database that will consolidate genetic, metabolic and lifestyle data. Now, for clinical integration of PM to become reality, the most important hurdle is not of scientific nature but rather economic and behavioral or systemic.

Payers, i.e., governments, insurers and patients, are key to completely unlock PM's systematic use in the healthcare system. Financial cover for personalized drugs and genetic sequencing is, nonetheless, yet unestablished with the institutional payers that are in the scope of our study. Such payers are typically the government when regarding health insurance in terms of social insurance or the private insurers when looking at private health insurance coverage. Today, most often we lack commonly accepted figures on clinical utility and cost-efficiency of PM. This renders insurers rather skeptical (Cohen et al. 2013; Trosman et al. 2015; Messner et al. 2016) and keeping policymakers from listing such drugs and treatments in the catalog of what social security and social health insurance cover. Additionally, as we are still in the infancy of PM, payers must invest in the short term but the benefits are to be reaped in the long run. This is especially critical in (private) insurance contracts where patients can switch their insurance provider and thus deter companies to consider longer terms. To counter the paucity of cost-efficiency evidence, "first-mover" payers are needed to cover the treatments and to generate enough data. Thereby, governments and pharmaceutical companies may play an important role since private insurers tend to selectively only cover proven drugs. Indeed, one key challenge is to provide a means to generate data and knowledge while limiting costs.

In this systematic literature review, we analyze the different challenges for integrating PM into healthcare systems from the payers' perspective. The viewpoint and the obstacles that payers stumble upon when it comes to financing PM have seldom been investigated. This paper fills this gap and gathers the extant body of knowledge. After a presentation of the methodology used for selecting articles in Section 2, the remainder of this paper logically follows the challenges faced by the payers when assessing PM. In Section 3, we document the economic relevance of PM with an emphasis on the lack of evidence and the potential remedies to the issue. In Section 4, we expose the governance challenges that impede PM coverage with a selection of possible solutions to tackle them. Finally, in Section 5, we develop on what characteristics slow down the integration of PM into the healthcare system and how to overcome them. We conclude the paper with a discussion in Section 6. In Appendix A we provide a comprehensive synopsis of the reviewed papers.

\section{Methodology}

\subsection{Review Strategy}

To conduct our literature review, we use the Preferred Reporting Items for Systematic Reviews and Meta-Analyses (PRISMA) protocol (Moher et al. 2015). To build the initial catalog of publications for review, we search the Web of Science Core Collection database. ${ }^{1}$ The extraction of bibliography entries is performed on the 28 October 2019. Thereby, we have included all available literature (published from 1900 onward) in all languages.

1 The Web of Science Core Collection is a curated bibliographic database containing peer-reviewed scholarly journals, books and conference proceedings published worldwide in the sciences, social sciences, and arts and humanities disciplines. It is available at http:/ / isiknowledge.com/wos. 
Our systematic review consists of the five steps outlined in Figure 1. The original corpus of publications is extracted from the Web of Science considering all documents referring to personalized health or healthcare, with respect to precision, individualized, personalized, stratified or genetic medicine. Further, we require the results to contain a link to health insurance, payers or reimbursements. ${ }^{2}$ To be exhaustive, we include the various spellings of PM as well as words affiliated to the same concept of medicine (Pokorska-Bocci et al. 2014). In this first step we identify 419 records for further screening.

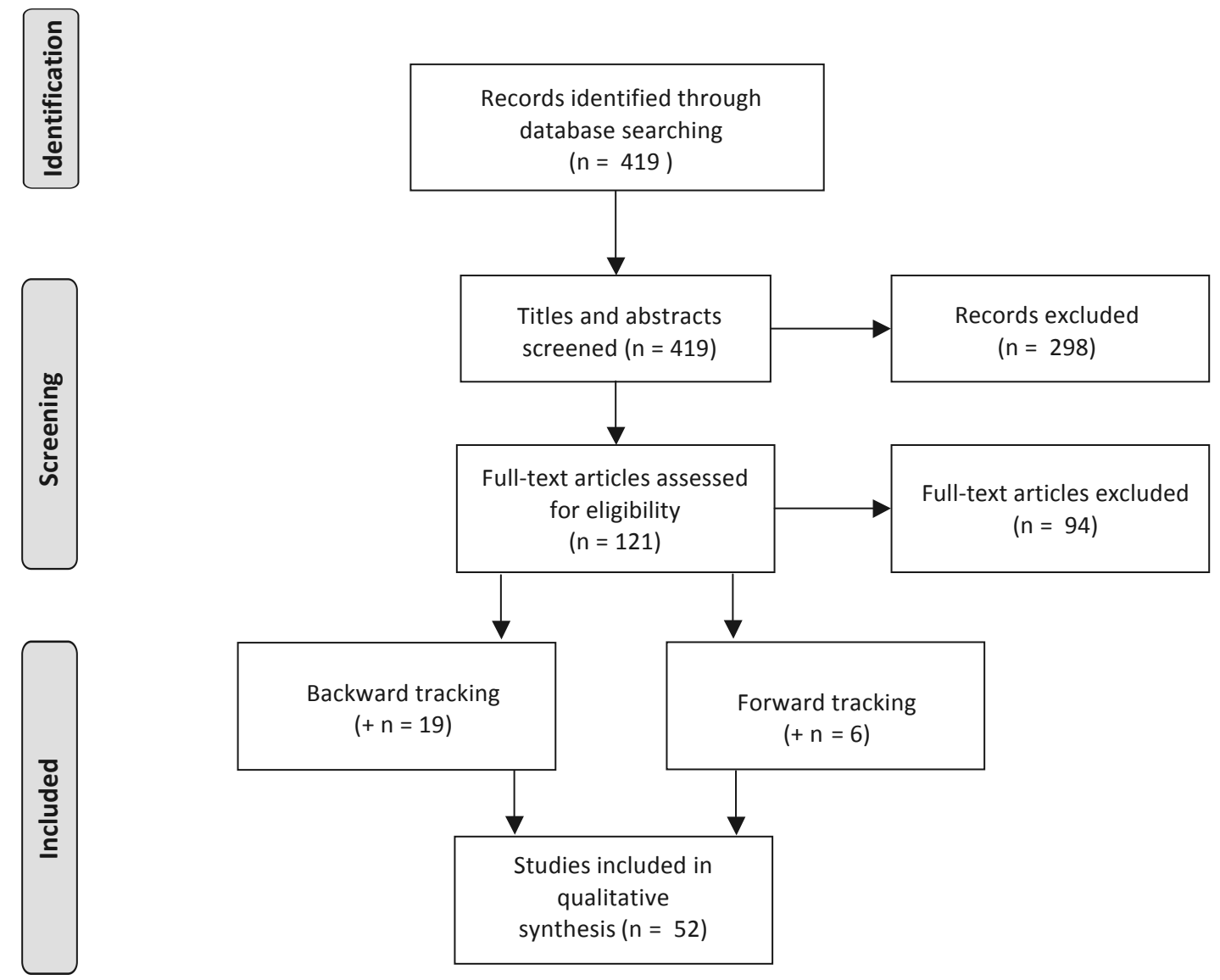

Figure 1. PRISMA review protocol based on Moher et al. (2015).

In the second and third steps of the protocol, we manually scan the titles and abstracts. In the selection process, we retain literature relevant to one of our themes of interest, i.e., the payment for PM, the existence of reimbursement strategies, and the implementation of PM into the current health insurance paradigm. We exclude 298 records that are not in the scope of our review. The assessment of the eligibility of the full text of the remaining 121 publications yields 94 exclusions. Subsequently, the fourth and fifth steps consist of backward and forward tracking. In backward tracking, we browse the bibliography of the 27 retained publications to select citations that are beyond the selection criteria of our first step but relevant for the review. Regarding forward tracking, we investigate Google Scholar

2 The full query used is as follows: (ALL = "personalized health" OR ALL= "personalized health" OR ALL= "personalized healthcare" OR ALL= "personalised healthcare" OR ALL= "personalized health care" OR $A L L=$ "personalised health care" OR ALL= "precision medicine" OR ALL= "individualized medicine" OR $A L L=$ "individualised medicine" OR ALL= "personalized medicine" OR ALL= "personalised medicine" OR ALL = "stratified medicine" OR ALL= "genetic medicine" OR ALL= "genomic medicine") AND (ALL = "health insur*" OR ALL= "payer*" OR ALL ="reimbursement"). 
relevant publications that cite one of the retained articles from the third step. In the Appendix A we summarize the reviewed papers along their focus, the methodology used, and the key contents with the main provided results.

Throughout the scanning of the literature, we outline three major topics. All relevant literature is falling into at least one of the following subjects:

1. Economic relevance of PM. Insurers as rational economic agents need proof of the cost-effectiveness of PM technologies before granting coverage. We include all literature that provides evidence, economic indicators related to PM, and tools and methods to foster the building of evidence. This includes but is not restricted to the two major approaches, i.e., contracts between manufacturers and payers to generate the evidence and standardization of data provision by assessment bodies.

2. Governance challenges. In this stream we include literature that tackles the heterogeneity for inter- and intra-countries PM coverage. This includes, for example, papers that highlight the emerging discrepancies from the existence of a myriad of contracts, the standardization of reimbursement thresholds, and the need for enhanced communication between stakeholders.

3. Healthcare system implementation. Here, we are interested in all actionable ideas to overcome the hurdles linked to, for example, technology and pricing, that impede a successful implementation in current healthcare systems. Insights to overcome these obstacles include, for example, risk-sharing or evidence development contracts between manufacturers and payers.

The first author handled the selection and scoping of the papers. The second author conducted the proof-reading to validate the collection. In case of disagreement, both authors discussed and reached a consensus. Additionally, both authors carried out a synopsis of the reviewed papers by extracting for each paper the region under study, the methodology used, the key contents and main results as well as the main topics the paper addresses.

\subsection{Synopsis of the Results}

Throughout the review that we present in detail in the following sections, we observe several recurring issues that the institutional payers face when dealing with PM. These challenges cover three dimensions-economic relevance (see Section 3), governance (Section 4) and implementation in the healthcare system (Section 5). Put briefly, the available evidence of economic efficiency is thin, of heterogeneous quality and assessed using too many different ad hoc metrics. This hurdle impedes or delays coverage and patient access to PM. To overcome this, potential solutions include manufacturer-payer partnerships and public subsidies to generate evidence, coupled with the establishment of universal health technology assessment (HTA) methodologies, the harmonization of guidelines and the economic requirements to address data quality. The second obstacle is the observed heterogeneity in coverage for PM technologies on various levels, internationally, as well as at the countries' scale. This can be attributed to multiple factors, among them a lack of standardization as highlighted above, the existence of a myriad of payer-manufacturer contracts and the in-place national healthcare scheme. Possible manners to unify coverage are the centralization of HTA to exclude discrepancies, clearer communication among stakeholders and the sharing of information beyond country borders. Finally, an assessment of the characteristics of PM highlights the underlying difficulties that payers encounter. Among them, we find that gene-based tests and diagnostics are deemed as experimental or investigational and without a clear actionable outcome. High costs also often characterize PM technologies along with a difficulty in predicting future expenses. To tackle this final issue, diverse approaches are possible. While few authors emphasize on the necessity to move to value-based pricing and coverage, others present numerous means to alleviate the financial burden of PM (e.g., multiyear contracts, health currency and government interventions). Authors also expose rather successful examples of PM inclusion in the healthcare system with payer-manufacturer partnerships such as price-volume agreements, usage caps or pay-for-performance contracts. 


\section{Economic Relevance: Lack of Evidence and Efficiency Metrics}

\subsection{Description of the Challenges}

$\mathrm{PM}$ is an emerging field and as of today, we do not have enough hindsight about its economic relevance. The insufficient amount of documentation regarding real-world data, i.e., the cost-effectiveness of a personalized drug or treatment after its implementation into clinical practice, is highlighted in the literature. For instance, Terkola et al. (2017) conducted a literature review to identify studies that confront randomized controlled trial results (performed before the introduction of the drug) with later-obtained data from clinical practice: they find such studies nonexistent. A large number of papers they reviewed either emphasize this issue or ask the reader to bear it in mind. Among the 26 papers mentioning economic relevance, more than $60 \%$ bring up the lack of studies assessing the applicability of PM. While some articles simply mention the issue (Degtiar 2017; Amendola et al. 2019), others blame the paucity of evidence as being one of the hurdles the field must overcome to enable an optimal coverage (Deverka et al. 2007; Sullivan et al. 2011; Faulkner et al. 2012; Fugel et al. 2012; Hresko and Haga 2012; Cohen et al. 2013; Terkola et al. 2017). Without clear documentation on the cost-effectiveness of PM, payers do not have any incentive to reimburse it as it is not proven to make sense economically. Alongside this uncertainty, payers admit being skeptical regarding the clinical usefulness of PM drugs and technologies. In the paper by Graf et al. (2013), 50\% of the assessed private payers report the need of evidence for clinical utility. On this topic, we observe a particular focus on pharmacogenomic/pharmacogenetic tests (PGx) and companion diagnostics (CDx). These tests link the individual's genetic variations to drug responses to provide the optimal drug and determine the appropriate dosage. The same ascertainment is made by Deverka (2009) in an overview of evidence for PGx. The drug management following the CDx, i.e., the effective use of the right drug at the right dosage to maximize efficacy, is questioned. Several other authors account for this issue, among them Deverka et al. (2007), Meckley and Neumann (2010), Sullivan et al. (2011), Hresko and Haga (2012), Faulkner et al. (2012), Cohen et al. (2013), Merlin et al. (2013), Towse and Garrison (2013), Cohen and Felix (2014), Terkola et al. (2017), Phillips et al. (2017) and Lu et al. (2018). The unclear outcome of PGx, CDx testing or more broadly PM, holds payers back from covering such procedures. There remains a high level of uncertainty about the compliance of the patient or health practitioner to the results of the CDx or PGx tests and to a more efficient drug use.

Regarding current available evidence, it is rather scarce, heterogeneous in terms of quality and used metrics, and payers consider it as insufficient to offer coverage. There is no universal evidentiary standard and authors navigate through cost-utility and cost-effectiveness analysis with various outputs like, for example, cost per quality-adjusted life years (QALY), cost per life years gained or incremental cost-effectiveness ratio (Simeonidis et al. 2019). HTA is a process designed to appraise the value of a drug or technology by asserting its cost-effectiveness, safety, clinical utility, and, when considered, social aspects. The outcome of the evaluation serves decision-makers regarding coverage and reimbursement. So far, despite the efforts of several HTA agencies such as the National Institute for Health and Care Excellence (NICE) in the United Kingdom, the Haute Authorité de Santé (HAS) in France or the Institute for Quality and Economic Efficiency in Healthcare (IQWiG) in Germany, no standard framework has been adopted. In a systematic review of pharmacogenetics and genomic screening programs, Vegter et al. (2008) underlined the absence of standardization in HTA among the reviewed studies. The Lancet Oncology Commission comes to the same conclusion regarding cost-effectiveness analysis of PGx and adds that this lack of harmonization hinders reimbursement (Sullivan et al. 2011). In the following years, authors point out the lack of a clear evidentiary framework in PM. According to Hall and McCabe (2013), "the standards for establishing evidence on effectiveness and cost-effectiveness of personalized medicine technologies are considerably less well-defined than those for conventional health technologies". In their literature review, Knowles et al. (2017) reported that $16 \%$ of the assessed papers are discussing "conflicting and unclear evidentiary standards in regulations". The same observation is made by Miller et al. (2011), Faulkner et al. (2012), 
Fugel et al. (2012), Messner et al. (2016), Knowles et al. (2017) and Simeonidis et al. (2019). When there is no governmental institution for the HTA, each payer has its cost-effectiveness and clinical utility standards and without a clear framework for assessing PM, the field presents heterogeneous evidence. Finally, Meckley and Neumann (2010) conclude their case study on six paired genetic tests and treatments by understanding that "more generous reimbursement of PM technology likely awaits more high-quality evidence", thereby summarizing both obstacles, the quantity of cost-efficiency data and its quality.

\subsection{Discussion of Potential Solutions}

We group possible ways to deal with the aforementioned issues in two approaches: top-down and bottom-up. The top-down approach consists of establishing standards for the HTA at a national or international level. The bottom-up approach resides in the creation of data through contracts between payers and manufacturers. Each approach tackles the issue differently. On the one hand, by standardizing the HTA, manufacturers will present harmonized evidence, which is of equal, deemed sufficient, quality to be assessed and the product to access the market. Subsequently, the payers will have access to these data and be able to make a well-informed decision. On the other hand, if the partnership alternative is favored, the data generated via these contracts will correspond exactly to the needs of the payer to assess the cost-efficiency or value of a particular drug or technology.

From the reviewed papers, Miller et al. (2011), Garfield (2011), Payne and Annemans (2013), Vozikis et al. (2016), Lu et al. (2018), Lu et al. (2018) and Simeonidis et al. (2019) agree on the standardization of HTA to be a valid solution. Be it on an international level (Terkola et al. 2017), European level for European Union countries (Garfield 2011) or at a national level. They assert that the benefit of standardization would lie in a harmonized and clear regulation of economic requirements for the HTA agencies to follow, thus facilitating the assessment process. Knowles et al. (2017) take a step further and recommend an alignment between regulators and payers on data specification. Both measures, the standardization of economic requirements and the alignment between stakeholders will homogenize the requirements and the assessment process to develop a common evidence base. The United Kingdom is a good example of HTA process standardization where NICE is responsible for assessing both efficacy and efficiency of a treatment, to subsequently give recommendations for its administration by the National Health Service (NHS). NICE's cost-effectiveness threshold ranges from $£ 20,000$ to $£ 30,000$ per QALY (McCabe et al. 2008). Only if a drug is below the threshold, it is recommended for the provision by the NHS. In a comparative assessment of European reimbursement systems conducted on behalf of the Personalized Medicine Coalition, Garfield (2011) graded ten countries' market access for PM technologies. Among the evaluated European countries, the United Kingdom received the best score in two criteria, the HTA process for diagnostics and the HTA process for companion products, confirming the straightforward nature of the appraisal process. Finally, Miller et al. (2011) qualify the United Kingdom's practices as "perhaps the best developed technology evaluation and medico-economic assessment system". The United Kingdom, thus, illustrates a successful standardization of the HTA process.

Regarding the bottom-up approach, there are several manners to constitute quality real-world data that are already in place for similar issues touching any drug. Thomas et al. (2010) suggested that reimbursement systems should foster evidence development. The first method is to find coverage with evidence development (CED) agreements. CEDs are contracts between a payer and a manufacturer, where the former commits to providing its members temporary coverage for an "investigational" or "experimental" drug or technology. In return, the latter must enroll these members in a payer-approved clinical program destined to generate enough evidence for the payer to make an informed decision about the continuation of the coverage (Garrison et al. 2013; Akhmetov and Bubnov 2017; Lu et al. 2018). The use of CEDs permits the generation of real-world data that are then used to compute the final cost-effectiveness estimate. This type of contract is in use for "regular" drugs in several countries like Sweden or the Netherlands where, according to 
Ferrario and Kanavos (2015), there were 29 and 52 CEDs, respectively, in 2015. The Netherlands has been a recurring example of public-private partnerships between payers and manufacturers (Akhmetov and Bubnov 2017; Faulkner et al. 2016; Ferrario and Kanavos 2015; Garrison et al. 2013).

In both the Netherlands and Sweden, however, these contracts are not used at first instance, they are introduced after a drug's inconclusive results of efficacy or high price. In other countries, these agreements are also expanding. In a survey conducted by Cohen and Felix (2014) among Medicare payers, 9 out of 11 responded that they would adopt CED contracts to build improved evidence for CDx. However, even though authors are enthusiastic about the issues this form of partnership addresses (Chalkidou and Rawlins 2011; Hresko and Haga 2012; Sullivan et al. 2011), they must be used with caution as CEDs do have several drawbacks. First, it is unclear who should bear the financial burden of demonstrating the clinical utility. Lu et al. (2018) stated that the costs would remain with the manufacturer. However, according to Lu et al. (2015) for instance, the Australian government has funded evidence generation in the past, and manufacturers did not share the costs. Subsequently, as reported by Garrison et al. (2013), in the United States, drugs on CED contracts between Medicare and manufacturers have not been de-listed even after being proved to offer only little advantage with the potential cost of increased risk of mortality. Boon et al. (2015) make a similar observation in the Netherlands. In a subsample of 46 orphan drugs, none of them have been de-listed even if showing little evidence of cost-effectiveness. Besides the fact that the delay for evidence building (four years in the Netherlands for instance) is considered as rather short, pressure from the public and ethics makes the de-listing on the sole cost-effectiveness criteria difficult. Finally, Garrison et al. (2013) pointed out the importance of a well-defined contract between the two parties as both may engage in suboptimal behavior. The conditions regarding the outcomes must be specified, such as the price discount, if the drug does not meet the target or in case of delay of data delivery.

Another manner to promote data collection is to resort to public financing. Several authors emphasize on the role of the government in the provision of healthcare (Vozikis et al. 2016) and hence its participation in evidence generation. Deverka (2009) and Towse and Garrison (2013) suggested the participation of the State by subsidies or public investments while Simeonidis et al. (2019) propose that "State-owned research institutions and universities" work along the private sector.

Finally, a third solution arises through data sharing. Lu et al. (2018) proposed a collaborative model, which collects and shares all existing health data. Thereby, they envision to use existing data from electronic health records and merge them with clinical outcomes from genetic interventions and insurance claims to obtain a comprehensive flow of information. The idea is to get large national databases containing genotype-phenotype-linked information. Such database would enable the combination of genetic data through test results and further costs from the usage of these tests through insurance claims.

Despite the relative novelty of the field, some solutions to current issues are present. The quality of the evidence of the cost-effectiveness of PM can be tackled by harmonization of HTA processes at an international scale, whereas specific coverage agreements can promote further evidence generation.

\section{Governance: Heterogeneity in Coverage}

\subsection{Description of the Challenges}

PM being in its infancy, policymakers and insurers only slowly adapt their coverage guidelines. A few papers review the patient reimbursement systems and coverage for PM technologies of European countries. When comparing reimbursement strategies, Garfield (2011) noted that each country has a specific HTA and reimbursement process. Because of these disparities, Miller et al. (2011) described the European HTA system as decentralized, hence less effective, and qualify the market penetration of PM as "minimal". In subsequent studies, Fugel et al. (2012) and Payne and Annemans (2013) still observe substantial differences in coverage among European countries and others in the world (Degtiar 2017). 
On closer inspection, this heterogeneity is present in countries sharing some common characteristics. For example, Italy and Germany have been mentioned to have discrepancies in reimbursement and coverage strategies because of their decentralized healthcare systems. Garfield (2011) presented the example of these specific countries where there is a significant difference among regions in terms of coverage for PM. The author further exposes that in Europe, reimbursement and HTA schemes can be made either nationally or regionally whereas regulatory decisions are made at the largest level, centrally or nationally. This creates delays and eventually inconsistencies in the coverage and reimbursement within a country. At a finer granularity, this observation is shared for the United States as well by Deverka (2009), Hresko and Haga (2012) and Lu et al. (2018). The case of the United States is slightly different because besides the diversity along the states there is another level of decision-making. Indeed, each payer has its own guidelines and evaluation of PM-which translates into coverage disparities among public and private stakeholders.

The discrepancies in coverage can be attributed to the heterogeneous regulation. To decide whether to cover a PM drug or technology, social insurance needs to refer to established guidelines in addition to having sufficient evidence. Trosman et al. (2010) in their article understand that the variation in coverage among payers depends on the type of evidence used and the perception of this evidence. Based on findings from Schwarzer et al. (2015) and Simeonidis et al. (2019), there is no PM-specific willingess-to-pay (WTP) threshold, i.e., the highest price at which payers are willing to reimburse a medicine or test. Without such benchmark, each drug is assessed separately and by different criteria by each HTA institution.

On the country level, another source for disparities in the coverage is that assessment processes are not standardized. Fugel et al. (2012) added for the case of diagnostics that "there is no clear and consistent process for value assessment" in Western Europe and in the United States when compared to what is already in place in the United Kingdom with NICE. Following the results of a policy Delphi panel, Messner et al. (2016) reported that among 19 overall challenges for the clinical adoption of NGS, the foremost issue is that "different payers have different evidentiary standards for assessing clinical utility, leading to inconsistent policies on coverage and reimbursement for NGS-based testing".

Another reason explaining the existence of such disparities is the myriad of risk-sharing agreements (RSA, also called managed entry agreements, MEA, or patient access schemes, PAS). Briefly put, RSAs are contracts between a manufacturer and a payer designed to ease the integration of a specific drug or technology in clinical practice. The sharing of the risk lies in the payment amount, which is made dependent either on the clinical outcome, for example, increase in QALYs and reduction of side-effects, or the economic outcome linked to the cost-effectiveness of the technology. This outcome, which triggers and defines the price of the treatment, is agreed upon before signing the contract. This arrangement mitigates the risk taken by the payer on financing a treatment, which has not strictly proven effective yet (Antonanzas et al. 2019). Further, according to Antonanzas et al. (2019), another way of splitting risk is for the payer to co-finance additional evidence generation in exchange of patient treatment access to meet the requirements for cost-efficiency proof. These contracts can be diverse: some are conditional reimbursements such as CEDs seen previously, others are price-volume agreements. Different countries have different priorities, for example, the generation of evidence or accessibility of a drug, resulting in tailored agreements designed to address the country's most preoccupying issue and ending up in a puzzle of contracts (Ferrario and Kanavos 2015; Leopold et al. 2013). For instance, in Australia in 2015, among 98 contracts, some were outcome-based or financially based, some promoted evidence generation and others were hybrid, depending on the payer's priority (Lu et al. 2015). In the context of PM, usual financing through basic social insurance coverage can represent a challenge. Indeed, it is economically irrational for health insurers and other healthcare sponsors to cover PM without a clear idea of the clinical or cost-efficiency outcome. The above-mentioned contracts, hence, offer an alternative that should be seriously considered. 


\subsection{Discussion of Potential Solutions}

Several authors discuss the variations in the cover for PM technologies and present possible solutions. For instance, Miller et al. (2011), Fugel et al. (2012) and Lu et al. (2018) pleaded that the creation of one central HTA agency will reduce differences between payers on the one hand and foster innovation on the other hand. This centralization of the cost- and clinical-efficiency assessment will facilitate the drugs' review and coverage guarantee. The HTA institution would be able to define a WTP threshold and emit recommendations regarding coverage, thus reducing the number of stakeholders taking part in the process. Vozikis et al. (2016) add that a single HTA agency could aid the government to tackle selected priority issues. As discussed in Section 3.2, a valid alternative is also to go further and standardize regulations regarding assessment and coverage of PM drugs at a larger leve, for example, international. Nonetheless, as highlighted by Garfield (2011), Schwarzer et al. (2015) and Faulkner et al. (2016), the extension of a scheme for appraisal and coverage at an international level is cumbersome. Indeed, each country has its own infrastructure and healthcare system, which builds on the government's areas of priority in health management and may not, or hardly fit other objectives decided at a larger scale.

The need for more transparent communication is also a recurring matter when dealing with PM, along with an alignment between the conflicting partakers, the manufacturers and payers. Trosman et al. (2011), Akhmetov and Bubnov (2017), Knowles et al. (2017) and Lu et al. (2018) advocated that early and enhanced communication improves coverage. Early communication from the payers to the manufacturers about their requirements for evidence development will improve decision-making once the payers have the necessary data, reducing the need to create additional contracts. Further, information sharing among different payers would result in similar assessment schemes among payers. Thomas et al. (2010) asserted that reimbursement systems should develop clearer standards. Coupled with communication, collaboration between stakeholders is the next step for further PM integration. Garfield (2011), in her assessment of European reimbursement systems for $\mathrm{PM}$, concludes that "greater collaboration [...] should occur between the agencies involved in coverage and payment".

\section{Implementation in the Healthcare System: Characteristics of Pm}

\subsection{Description of the Challenges}

The first hurdle payers encounter while deciding whether to cover PM is the clinical relevance of certain procedures. In her review of PM coverage, Degtiar (2017) finds that among private payers, tests are deemed "experimental" and "investigational". This observation is recurrent through the literature, especially for NGS. Indeed, sequencing lies at the frontier between medically necessary and experimental or investigational technology as its purpose is to simultaneously inspect several genetic mutations; however, in many cases, without a clear actionable outcome. Additionally, when another pathogenic mutation is found, unrelated to the primary diagnostic, this so-called incidental finding can lead to confirmatory testings. The question of whether the following testings should be reimbursed is another issue payers must think through when deciding for NGS coverage. Overall, payers encounter difficulties in predicting costs as the presence of a mutation in an individual makes members of the family eligible for cascade testing, for example in the case of breast cancer screening (Amendola et al. 2019). This renders the final coverage decision difficult as mentioned by Trosman et al. (2018) and Trosman et al. (2015). The lack of cost predictability is one of the main reasons for coverage denial (Deverka and Dreyfus 2014; Messner et al. 2016; Trosman et al. 2010). In the same vein, Lu et al. (2018) assessed coverage for multigene testing to confirm findings that the private payers not covering the tests regard them as experimental or investigational. According to Amendola et al. (2019) and Trosman et al. (2017), germline and hereditary cancer panels suffer from the same hardship in getting coverage. PM in general suffers from the same pragmatic issue, as seen in Meckley and Neumann (2010) and Hresko and Haga (2012). 
The second hurdle is the high price of PM technology. By definition, PM drugs are targeted to small clusters of selected individuals. This spreads the costs of research and development on a narrower population (Thomas et al. 2010). Further, manufacturers producing drugs aimed at the treatment of rare diseases have high chances of becoming monopolists on specific markets. Such a setup typically comes with higher prices (Garrison and Austin 2006; Pauly 2019; Garrison and Towse 2017; Degtiar 2017). Concrete current examples are orphan drugs (Orofino et al. 2010; O'Sullivan et al. 2013; Schey et al. 2011). Several authors mention this characteristic of PM technologies as an additional obstacle to coverage. Degtiar (2017) emphasizes the increase in healthcare costs due to the increase in the number of orphan drugs on the market. The high price of personalized drugs and their impact on the total healthcare expenditure in the accounting period (e.g., the year) of the treatment is given. For PM drugs the time horizon for cost-efficiency studies needs to be different as such drugs often avoid the longer-term administration of other (cheaper) drugs.

\subsection{Discussion of Potential Solutions}

As healthcare evolves, the price and valuation of health technologies are to follow. Authors like Ramsey et al. (2006), Deverka (2009), Deverka and Dreyfus (2014), Carrera and IJzerman (2016) and Garrison and Towse (2017) mentioned the necessity to switch to a more comprehensive assessment of the value, the pricing and reimbursement of PM technologies. Kanavos and Angelis (2013), among others, proposed a framework for a value-based assessment of new medical technologies, which could easily be applied to PM. They suggest that the so-called multiple criteria decision analysis (MCDA) should incorporate parameters related to "value creation" complementing the efficacy and effectiveness criteria of a technology. They have elaborated on an MCDA tree for HTA that considers 12 criteria along four categories: the burden of illness, the therapeutic impact of the drug (which incorporates the efficacy and effectiveness parameters), the innovation level and the socioeconomic impact. Subsequently, weights are assigned to each criterion to compute scores for each option. This framework could be used to decide either for coverage or for price setting.

In view of the high prices at which the personalization of healthcare comes, it is necessary to seek the best financing schemes. The coverage of a drug, which could eradicate a health condition can be seen as an investment decision by the payer. However, under the current healthcare frameworks, the payer can sometimes not entirely capture the "benefits" of such investments in the following years (e.g., because the patient receiving the treatment quits the contract with the private insurer that has paid). A paper by Mattke et al. (2017) classifies multiple solutions to the issue insurers encounter when deciding to cover an expensive drug. Some could be applied to the case of PM. The authors propose multiyear contracts with possible compulsory applications in the case of gene therapies. A multiyear contract would bind the patient to the insurer that funded the cure. This enables the insurer to get the return of its investment in the following years, as benefits of a cure typically take longer than a year to emerge. In the same vein, a "health currency" is proposed as a monetization of health (initially presented by Basu 2015). The idea is that every investment in cures by public or private payers gives birth to "HealthCoins" that are transferable. When a patient later enrolls in a new health plan, the new insurer must buy out the health coins from the former payers. Thus, the insurer that invested in the cure will get partial reimbursement. This currency, hence, decreases the risk borne by the insurer. Other options include a cure fund or reinsurance for specific high-cost cures. Finally, the authors discuss government interventions such as patent buyout-where the manufacturer will be compensated for its investments in innovation, or tax coverage-where the expensive drugs and technologies can be directly funded through tax revenues.

To reduce the financial risk borne by the payer, RSA (or so-called MEA or PAS) are being implemented. These contracts can serve several aims simultaneously, such as reducing the risk of outcome uncertainty, with the example of CEDs (cf. Section 3.2), and granting patient access for high-priced drugs (Ferrario and Kanavos 2015; Lu et al. 2015; Faulkner et al. 2016; Akhmetov and Bubnov 2017; Degtiar 2017; Lu et al. 2018). In Figure 2, based on the payer engagement strategies presented 
by Akhmetov and Bubnov (2017, Fig. 1), we lay out the schemes that primarily address the high cost of new drugs.

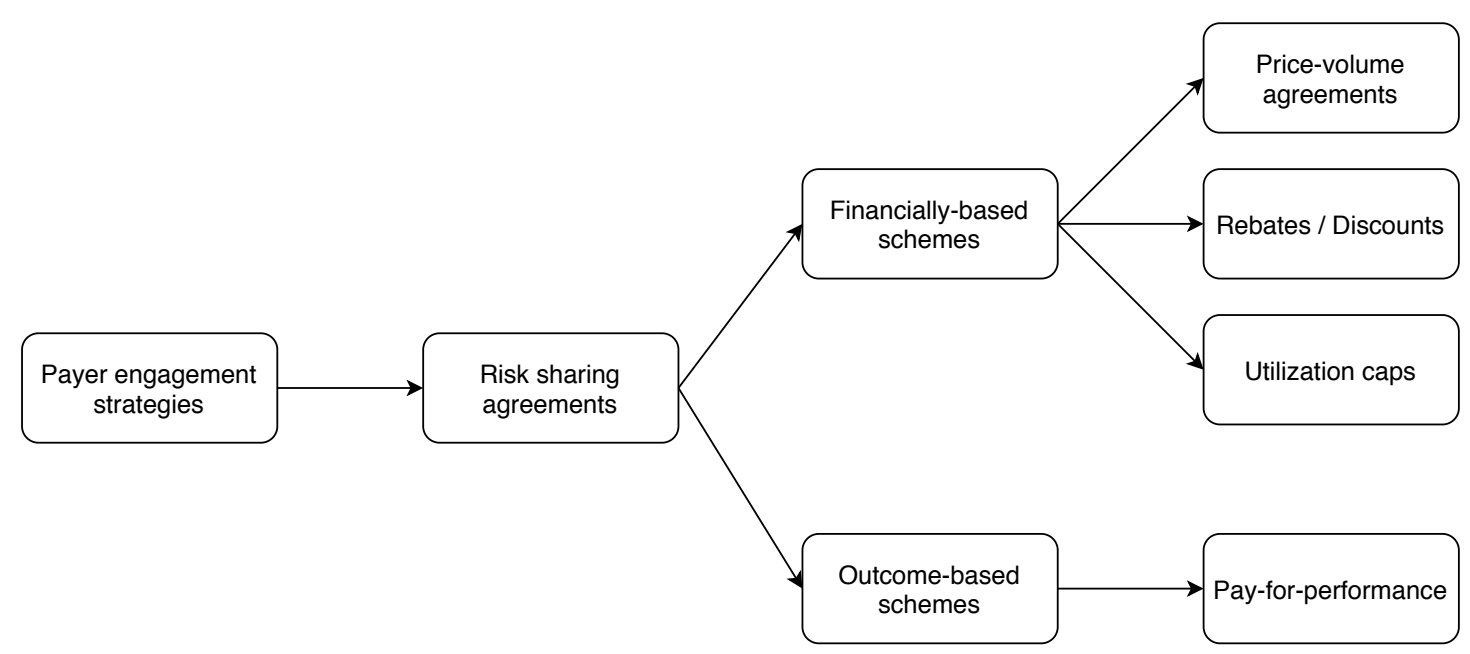

Figure 2. Examples of managed entry agreement (MEA) schemes for cost mitigation based on Akhmetov and Bubnov (2017).

Price-volume agreements (PVA) define a threshold of total expenditure and when the predefined amount is topped a discount is triggered. These agreements fix prices at a maximum level for a specific volume (Ferrario and Kanavos 2015). Faulkner et al. (2016) presented the cases of France and Germany where this type of contract is implemented for high-cost medicine. Similar to PVAs, caps set a maximum time or dose amount for the treatment to be efficient, above which the manufacturer pays for additional treatment continuation. These agreements are currently used in the United Kingdom (and more specifically in England, see Garrison et al. 2013, and Faulkner et al. 2016). Other solely price-based agreements between the manufacturer and payer, also in place in the United Kingdom, are rebates or discounts (Ferrario and Kanavos 2015). These agreements are purely economic and do not contain any outcome component. Another possibility for an institution to reduce the budget impact by high-priced drugs are traditional co-payment or cost-sharing procedures (Degtiar 2017; Garrison et al. 2013; Pauly 2019). Under this setting, the patient financially contributes to the costs for treatments, reducing the payer's participation (Faulkner et al. 2016). Finally, the presented pay-for-performance scheme in Figure 2 allows for payers to pay the manufacturer only in the case of success. This success is designated by both parties as the achievement of an agreed outcome, which may be a positive health outcome or simply a limitation of negative events (Akhmetov and Bubnov 2017; Faulkner et al. 2016).

Some of the above arrangements are already in place for non-PM technologies (Garrison et al. 2013; Ferrario and Kanavos 2015; Lu et al. 2015; Faulkner et al. 2016). Such methods could be successfully applied to PM to address the raised issues. Some of these contracts can be combined to address multiple barriers simultaneously, as seen, for example, in Australia (see Lu et al. 2015).

Finally, other types of cost-retaining strategies can be applied. Leopold et al. (2013) reported the case of trastuzumab, a personalized drug for HER-2 positive breast cancer patients, in Latvia. While the diagnostic test is reimbursed for all breast cancer patients, the treatment is subject to assessment. Due to a limited budget, the reimbursement of the treatment is analyzed on a case-by-case study, thus reducing expenses to only positive and deemed necessary cases. In the latter procedure, other non-economic questions arise, notably the decision on "necessity" in each case relating to ethical issues and the valuation of QALYs. 


\section{Concluding Discussion}

In our review of the PM literature and our assessment of the building blocks of PM from a payer's perspective, we reveal three major impediments for integrating PM in healthcare systems. The hardship comes from different areas: economic relevance, governance and practical implementation of PM in the healthcare system. Solutions are available but need to be properly put into practice. A common approach lies in the collaboration among partakers. Collaboration between manufacturers and institutional payers like a national social health insurance scheme or a private insurer will more easily and rapidly generate the necessary base of evidence for drug coverage. Cross-border collaborations between HTA agencies and payers would help achieve standard thresholds for the coverage of treatments. Finally, a close collaboration among the various payers themselves is necessary to provide unified coverage by sharing and harmonizing data.

In the building of the new paradigm, the implication of each stakeholder is necessary to ensure the financial management of PM. In particular, the payers and manufacturers are the enablers of the next phase of evolution toward an individualized medicine. On the one hand, payers are asked to take a leap of faith in contributing to evidence generation by covering PM drugs blindfolded on its real-world cost-efficiency. To secure the jump, manufacturers, governments and HTA bodies must establish guidelines and a standard procedure for PM technologies to be quickly assessed. On the other hand, the appraisal of coverage based on the calculation of pure economic costs should include the value created, for example, in terms of QALYs, by the use of personalized treatments. Finally, with the new outlook on healthcare, and especially with the necessity to at first invest in a system that may not yet be proven economically rational, health should be regarded as an investment in the long term rather than a cost in the short term.

Author Contributions: Conceptualization, V.K. and J.W.; methodology, V.K. and J.W.; formal analysis, V.K.; writing —original draft preparation, V.K.; writing—review and editing, V.K. and J.W.; supervision, J.W.; funding acquisition, J.W. All authors have read and agreed to the published version of the manuscript.

Funding: Financial support from the Swiss National Science Foundation (SNSF, grant no. CRSII5_180350).

Conflicts of Interest: The authors declare no conflict of interest.

\section{Abbreviations}

The following abbreviations are used in this manuscript:

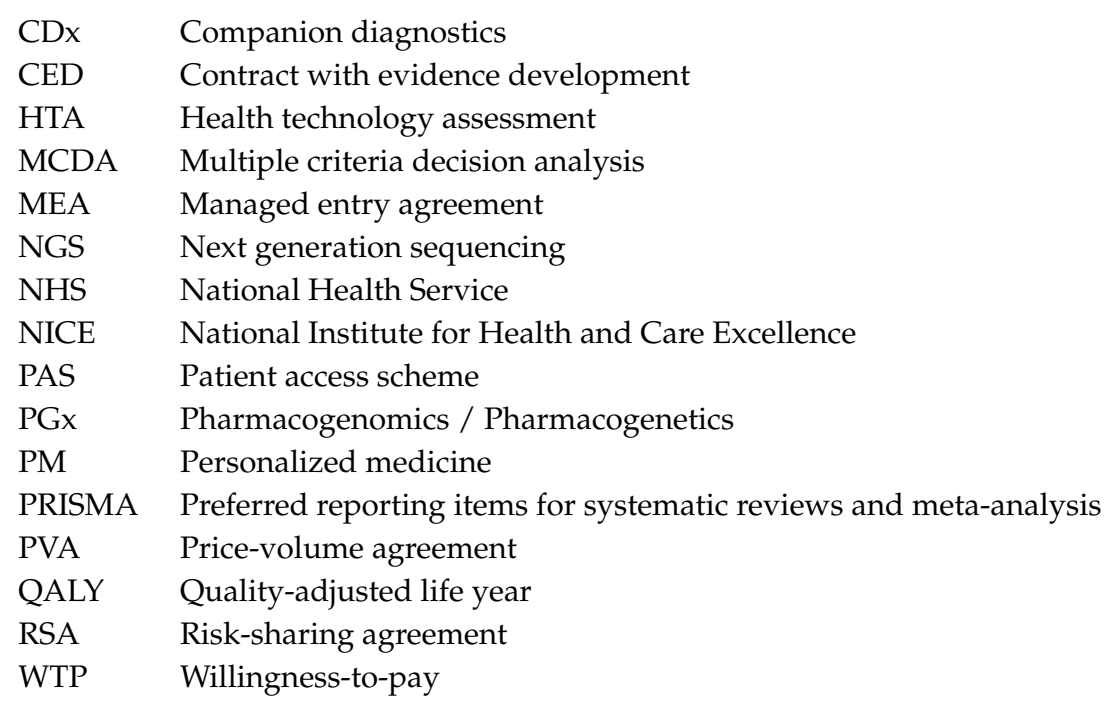

\section{Appendix A}

The following table provides a comprehensive overview of the 52 reviewed papers. 
Table A1. Synopsis of reviewed papers.

\begin{tabular}{|c|c|c|c|c|c|c|}
\hline Reference & Region & Methodology & Key Contents and Main Results & ER & GC & HS \\
\hline $\begin{array}{l}\text { Akhmetov and } \\
\text { Bubnov (2017) }\end{array}$ & US & $\begin{array}{l}\text { Survey/interviews } \\
(N=75)\end{array}$ & $\begin{array}{l}\text { - Manufacturers may benefit from accessing claims data } \\
\text { - Collaboration and trust are key, data exchange improves evidence paucity } \\
\text { - Early dialogue between producers and payers enables better integration }\end{array}$ & $\checkmark$ & $\checkmark$ & $\checkmark$ \\
\hline $\begin{array}{l}\text { Amendola et al. } \\
\text { (2019) }\end{array}$ & US & $\begin{array}{l}\text { Review of coverage } \\
(N=31)\end{array}$ & $\begin{array}{l}\text { - Guidelines not meaningfully identify patients who may benefit from testing } \\
\text { - Germline cancer test often deemed experimental or not medically necessary } \\
\text { - Difference in denial because of difference in evidence assessment }\end{array}$ & $\checkmark$ & & $\checkmark$ \\
\hline Basu (2015) & & Conceptual article & $\begin{array}{l}\text { - HealthCoins to address the "free-rider" problem among insurers } \\
\text { - HealthCoins to enable smooth investments across insurers } \\
\text { - HealthCoins are produced with investments and bought out by next insurer }\end{array}$ & & & $\checkmark$ \\
\hline Boon et al. (2015) & NL & Discussion & $\begin{array}{l}\text { - None of } 46 \text { orphan drugs on conditional reimbursement were de-listed } \\
\text { - De-listing solely on cost-effectiveness faces social pressure } \\
\text { - Four year re-evaluation for quality evidence production is too short }\end{array}$ & $\checkmark$ & $\checkmark$ & \\
\hline $\begin{array}{l}\text { Carrera and } \\
\text { IJzerman (2016) }\end{array}$ & & Discussion & $\begin{array}{l}\text { - PM drugs are particularly costly due to narrower customer base } \\
\text { - Stakeholders have different WTP thresholds per QALY } \\
\text { - MCDA incorporates in HTA the multidimensional value of PM }\end{array}$ & & & $\checkmark$ \\
\hline $\begin{array}{l}\text { Chalkidou and } \\
\text { Rawlins (2011) }\end{array}$ & & Discussion \& case studies & $\begin{array}{l}\text { - Discussion of interrelated impact between CED and pharmacogenetics } \\
\text { - CED contracts offer an alternative solution for public reimbursement } \\
\text { - Healthcare system has to be adjusted for optimal RSA implementation }\end{array}$ & $\checkmark$ & & \\
\hline $\begin{array}{l}\text { Cohen et al. } \\
\text { (2013) }\end{array}$ & US & $\begin{array}{l}\text { Review of } \\
\text { reimbursement } \\
(N=8 \text { PGx })\end{array}$ & $\begin{array}{l}\text { - Lack of comprehensive reimbursement of CDx and high costs of PGx } \\
\text { - Often low evidence of clinical usefulness } \\
\text { - Payers report that tests cost for everyone but help only a few }\end{array}$ & $\checkmark$ & & \\
\hline $\begin{array}{l}\text { Cohen and Felix } \\
\text { (2014) }\end{array}$ & US & $\begin{array}{l}\text { Review (10 drug- } \\
\text { diagnostics) and survey } \\
(N=11)\end{array}$ & $\begin{array}{l}\text { - Variable and relatively high patient co-insurance } \\
\text { - Drug reimbursement is not necessarily coupled with diagnostic coverage } \\
\text { - Need to increase the body of evidence; CED to increase data }\end{array}$ & $\checkmark$ & & \\
\hline Degtiar (2017) & 42 countries & $\begin{array}{l}\text { Literature review } \\
(N=69 \text { articles })\end{array}$ & $\begin{array}{l}\text { - Private payers deem tests investigational and cover them less } \\
\text { - Value-based assessment for reimbursement to incorporate other criteria } \\
\text { - Need for evidence guidelines from payers }\end{array}$ & $\checkmark$ & $\checkmark$ & $\checkmark$ \\
\hline $\begin{array}{l}\text { Deverka et al. } \\
\text { (2007) }\end{array}$ & US & $\begin{array}{l}\text { Survey/interviews } \\
(N=60)\end{array}$ & $\begin{array}{l}\text { - Lack of clinical utility as a barrier for molecular medicine coverage } \\
\text { - Public-private partnership for effectiveness research data generation } \\
\text { - Establishment of accurate regulation to avoid uncertainty }\end{array}$ & $\checkmark$ & & \\
\hline
\end{tabular}


Table A1. Cont.

\begin{tabular}{|c|c|c|c|c|c|c|}
\hline Reference & Region & Methodology & Key Contents and Main Results & ER & GC & HS \\
\hline $\begin{array}{l}\text { Deverka and } \\
\text { Dreyfus (2014) }\end{array}$ & & Review of NGS coverage & $\begin{array}{l}\text { - Lack of clinical utility information and standards } \\
\text { - Move reimbursement from a cost-based to a value-based approach } \\
\text { - Payers concerned with reimbursement of confirmation of incidental findings }\end{array}$ & & & $\checkmark$ \\
\hline Deverka (2009) & & Commentary & $\begin{array}{l}\text { - Payers have evidence requirements more rigorous than regulators } \\
\text { - Coverage assessment needs positive net benefit as compared to usual care } \\
\text { - Opportunity for informed decision-making by linking payer information }\end{array}$ & $\checkmark$ & $\checkmark$ & $\checkmark$ \\
\hline $\begin{array}{l}\text { Faulkner et al. } \\
\text { (2012) }\end{array}$ & US & Review & $\begin{array}{l}\text { - Research prioritization and early standardized value assessment } \\
\text { - Best practice for clinical evidence development/health economic assessment } \\
\text { - New incentive and reimbursement approaches for PM }\end{array}$ & $\checkmark$ & & \\
\hline $\begin{array}{l}\text { Faulkner et al. } \\
\text { (2016) }\end{array}$ & EU \& US & $\begin{array}{l}\text { Review of pricing and } \\
\text { reimbursement }\end{array}$ & $\begin{array}{l}\text { - Earlier cross-stakeholder engagement and regulatory tools } \\
\text { - Flexible and adaptive payer approaches to pricing and reimbursement } \\
\text { - Iterative evidence generation and specific funding }\end{array}$ & & $\checkmark$ & $\checkmark$ \\
\hline $\begin{array}{l}\text { Ferrario and } \\
\text { Kanavos (2015) }\end{array}$ & $\begin{array}{l}\mathrm{BE}, \mathrm{UK}, \mathrm{NL}, \\
\mathrm{SE}\end{array}$ & $\begin{array}{l}\text { Review of MEA } \\
(N=133)\end{array}$ & $\begin{array}{l}\text { - Conceptual framework for MEA agreements and tests } \\
\text { - Different types of agreement and medicine-indications across countries } \\
\text { - Variation from governance and risk-perception }\end{array}$ & $\checkmark$ & $\checkmark$ & $\checkmark$ \\
\hline Fugel et al. (2012) & EU \& US & $\begin{array}{l}\text { Review of pricing and } \\
\text { reimbursement }\end{array}$ & $\begin{array}{l}\text { - Lack of a consistent process for value assessment of more complex diagnostics } \\
\text { - More flexible pricing and reimbursement systems are needed } \\
\text { - Further development of framework for access of diagnostic-based therapies }\end{array}$ & $\checkmark$ & $\checkmark$ & \\
\hline Garfield (2011) & $\begin{array}{l}10 \mathrm{EU} \\
\text { countries }\end{array}$ & $\begin{array}{l}\text { Review of } \\
\text { reimbursement }\end{array}$ & $\begin{array}{l}\text { - European reimbursement systems are not appropriately aligned } \\
\text { - Change health technology assessment methodologies } \\
\text { - Need for integrated reimbursement pathways and drug coding systems }\end{array}$ & $\checkmark$ & $\checkmark$ & \\
\hline $\begin{array}{l}\text { Garrison and } \\
\text { Austin (2006) }\end{array}$ & & Commentary & $\begin{array}{l}\text { - Limitations of genetic prediction and lack of economic incentives slows PM } \\
\text { - Clinical successes often on a case-by-case basis } \\
\text { - Develop strong intellectual property and value-based, flexible pricing systems }\end{array}$ & & & $\checkmark$ \\
\hline $\begin{array}{l}\text { Garrison and } \\
\text { Towse (2017) }\end{array}$ & & $\begin{array}{l}\text { Concepts for pricing and } \\
\text { reimbursement }\end{array}$ & $\begin{array}{l}\text { - Take an economic perspective and a broader concept of value } \\
\text { - Valuations beyond QALY including changing preferences over life } \\
\text { - Inflexible or cost-based reimbursement systems as barriers for PM }\end{array}$ & & & $\checkmark$ \\
\hline $\begin{array}{l}\text { Garrison et al. } \\
\text { (2013) }\end{array}$ & & $\begin{array}{l}\text { Review of RSA } \\
(N=116)\end{array}$ & $\begin{array}{l}\text { - Performance-based risk-sharing arrangements to reduce uncertainty } \\
\text { - Practical recommendations for state-of-the-art methods } \\
\text { - Data regulation and long-run societal perspective needed }\end{array}$ & $\checkmark$ & & $\checkmark$ \\
\hline
\end{tabular}


Table A1. Cont.

\begin{tabular}{|c|c|c|c|c|c|c|}
\hline Reference & Region & Methodology & Key Contents and Main Results & ER & GC & HS \\
\hline Graf et al. (2013) & US & $\begin{array}{l}\text { Review of coverage } \\
(N=206 \text { policies })\end{array}$ & $\begin{array}{l}\text { - Half of insurers do not cover specific genetic-related services } \\
\text { - One-third of the insurers addressed genetic testing } \\
\text { - Challenges in ensuring consistency and homogeneity among insurers }\end{array}$ & $\checkmark$ & & \\
\hline $\begin{array}{l}\text { Hall and McCabe } \\
\text { (2013) }\end{array}$ & & Commentary & $\begin{array}{l}\text { - Cost-effectiveness standards are more poorly defined for PM } \\
\text { - Regulation of diagnostic tests less rigorous } \\
\text { - Harmonize methods and increase modeling transparency }\end{array}$ & $\checkmark$ & & \\
\hline $\begin{array}{l}\text { Hresko and Haga } \\
\text { (2012) }\end{array}$ & US & $\begin{array}{l}\text { Review of coverage } \\
(N=41 \text { policies })\end{array}$ & $\begin{array}{l}\text { - Lack of evidence of clinical utility as a barrier for coverage } \\
\text { - Variable coverage determinations and factors considered } \\
\text { - Inclusion of PGx information in drug package inserts seems relevant }\end{array}$ & $\checkmark$ & $\checkmark$ & $\checkmark$ \\
\hline $\begin{array}{l}\text { Kanavos and } \\
\text { Angelis (2013) }\end{array}$ & & $\begin{array}{l}\text { Concept for value } \\
\text { assessment }\end{array}$ & $\begin{array}{l}\text { - Multiple criteria decision analysis: HTA for broader value inclusion } \\
\text { - Values: illness burden, innovation, therapeutic and socioeconomic impact } \\
\text { - Score: weights are assigned according to an institution's priorities }\end{array}$ & & & $\checkmark$ \\
\hline $\begin{array}{l}\text { Knowles et al. } \\
\text { (2017) }\end{array}$ & & $\begin{array}{l}\text { Literature review } \\
(N=344 \text { articles })\end{array}$ & $\begin{array}{l}\text { - Science of PM requires broadening beyond genetics } \\
\text { - Lack of clinical uptake due to structural and human factors } \\
\text { - Recommendations on financial and regulatory barriers to be addressed }\end{array}$ & $\checkmark$ & $\checkmark$ & \\
\hline $\begin{array}{l}\text { Leopold et al. } \\
\text { (2013) }\end{array}$ & $\begin{array}{l}27 \mathrm{EU} \\
\text { countries }\end{array}$ & Survey $(N=27)$ & $\begin{array}{l}\text { - In the EU four broad models for PM funding (case study trastuzumab) } \\
\text { - Most EU countries: combined hospital and 3rd party payer strategy } \\
\text { - No combined funding for diagnostic test and medical treatment }\end{array}$ & & $\checkmark$ & $\checkmark$ \\
\hline Lu et al. (2018) & US & $\begin{array}{l}\text { Review of coverage } \\
(N=18 \text { payers })\end{array}$ & $\begin{array}{l}\text { - Important variation among guidelines, especially in private payers } \\
\text { - A second HTA agency assessment could reduce coverage variation } \\
\text { - Increased dialogue and sharing prior information to reduce coverage variation }\end{array}$ & $\checkmark$ & $\checkmark$ & $\checkmark$ \\
\hline Lu et al. (2015) & $\begin{array}{l}\text { Asia-Pacific } \\
\text { countries }\end{array}$ & Literature review & $\begin{array}{l}\text { - Most PAS focus on pharmaceuticals, few on medical technologies } \\
\text { - Majority involve pricing arrangements, evidence generation rarely used } \\
\text { - Australia has strong experience with PAS }\end{array}$ & $\checkmark$ & $\checkmark$ & $\checkmark$ \\
\hline Lu et al. (2018) & & Commentary & $\begin{array}{l}\text { - Clinical utility unanswered for many genomic technologies } \\
\text { - Propose building blocks for rapid generation of evidence } \\
\text { - Proven analytical and clinical validity needed, collaborative models for action }\end{array}$ & $\checkmark$ & & $\checkmark$ \\
\hline $\begin{array}{l}\text { Mattke et al. } \\
\text { (2017) }\end{array}$ & & Discussion & $\begin{array}{l}\text { - Policy options to remedy the "free-rider" problem with high-cost cures } \\
\text { - Incentives for patients, coordination among payers, government intervention } \\
\text { - Collaborations for equitable mechanisms for cost-benefits distribution }\end{array}$ & & & $\checkmark$ \\
\hline
\end{tabular}


Table A1. Cont.

\begin{tabular}{|c|c|c|c|c|c|c|}
\hline Reference & Region & Methodology & Key Contents and Main Results & ER & GC & HS \\
\hline $\begin{array}{l}\text { McCabe et al. } \\
(2008)\end{array}$ & UK & Commentary & $\begin{array}{l}\text { - NICE is the only entity to assesses effectiveness and cost-effectiveness } \\
\text { - Cost-effectiveness threshold of NICE is } £ 20,000 \text { per QALY } \\
\text { - Threshold should be regularly re-evaluated to match budget and innovation }\end{array}$ & $\checkmark$ & & \\
\hline $\begin{array}{l}\text { Meckley and } \\
\text { Neumann (2010) }\end{array}$ & US & $\begin{array}{l}\text { Case studies of } \\
\text { diagnostics and } \\
\text { treatments }(N=6)\end{array}$ & $\begin{array}{l}\text { - Strength of evidence is the strongest predictor for drug reimbursement } \\
\text { - Regulatory oversight and cost-effectiveness not associated to reimbursement } \\
\text { - Absence of coverage triggers direct-to-consumer marketing }\end{array}$ & $\checkmark$ & & $\checkmark$ \\
\hline $\begin{array}{l}\text { Merlin et al. } \\
(2013)\end{array}$ & Australia & $\begin{array}{l}\text { Review of } \\
\text { reimbursement }\end{array}$ & $\begin{array}{l}\text { - Safety, effectiveness, and cost-effectiveness for reimbursement decisions } \\
\text { - Linkage of different types of evidence and likely clinical benefits of drugs } \\
\text { - Framework allows merging different data sources to increase the database }\end{array}$ & $\checkmark$ & & \\
\hline $\begin{array}{l}\text { Messner et al. } \\
(2016)\end{array}$ & US & $\begin{array}{l}\text { Policy Delphi panel } \\
(N=48)\end{array}$ & $\begin{array}{l}\text { - Proprietary variant databases are a key challenge for NGS coverage } \\
\text { - Payer policies and perceived inconsistency in standards as a barrier } \\
\text { - FDA regulation not strongly perceived as a barrier }\end{array}$ & $\checkmark$ & $\checkmark$ & $\checkmark$ \\
\hline Miller et al. (2011) & EU & Market study & $\begin{array}{l}\text { - Insufficient clarity on reimbursement and regulatory pathways for PM tests } \\
\text { - Value-based public sector pricing required in Europe } \\
\text { - EU market suffers from decentralization }\end{array}$ & $\checkmark$ & $\checkmark$ & \\
\hline Pauly (2019) & & Review of coverage & $\begin{array}{l}\text { - Study on patterns of insurance coverage for PM and efficiency } \\
\text { - Heterogeneity in marginal benefits call for partial coverage } \\
\text { - Case studies: tests providing more benefits than costs should be fully covered }\end{array}$ & & & $\checkmark$ \\
\hline $\begin{array}{l}\text { Payne and } \\
\text { Annemans (2013) }\end{array}$ & EU & Literature review & $\begin{array}{l}\text { - Successful market access driven by generation of robust evidence } \\
\text { - Take account of the different stakeholders' perspectives } \\
\text { - Suggestion of possible approaches and necessary timescales }\end{array}$ & $\checkmark$ & $\checkmark$ & \\
\hline $\begin{array}{l}\text { Phillips et al. } \\
\text { (2017) }\end{array}$ & US & $\begin{array}{l}\text { Review of coverage } \\
(N=55 \text { policies })\end{array}$ & $\begin{array}{l}\text { - Multigene tests do not fit standard coverage framework } \\
\text { - High degree of variability in coverage assessment for multigene tests } \\
\text { - Payers deny coverage because of lack of evidence and actionability }\end{array}$ & $\checkmark$ & & \\
\hline $\begin{array}{l}\text { Ramsey et al. } \\
(2006)\end{array}$ & & Commentary & $\begin{array}{l}\text { - Currently, reimbursement is based on the price rather than clinical value } \\
\text { - Reimbursement to move to an evidence- and value-based paradigm } \\
\text { - Standardize presentation and filling information gap benefits all }\end{array}$ & & & $\checkmark$ \\
\hline $\begin{array}{l}\text { Schwarzer et al. } \\
\text { (2015) }\end{array}$ & 11 countries & Review of thresholds & $\begin{array}{l}\text { - Explicit cost-effectiveness thresholds only in two countries (UK and TH) } \\
\text { - Implicit values in other countries and different decision-making rules } \\
\text { - No PM-specific threshold found }\end{array}$ & & $\checkmark$ & \\
\hline
\end{tabular}


Table A1. Cont.

\begin{tabular}{|c|c|c|c|c|c|c|}
\hline Reference & Region & Methodology & Key Contents and Main Results & ER & GC & HS \\
\hline $\begin{array}{l}\text { Simeonidis et al. } \\
\text { (2019) }\end{array}$ & & $\begin{array}{l}\text { Literature review } \\
(N=96 \text { articles })\end{array}$ & $\begin{array}{l}\text { - Outcome of interventions mostly measured in QALYs } \\
\text { - Total cost estimated upon direct medical cost data } \\
\text { - Need for cost-utility analyses within national healthcare systems }\end{array}$ & $\checkmark$ & $\checkmark$ & \\
\hline $\begin{array}{l}\text { Sullivan et al. } \\
\text { (2011) }\end{array}$ & $\begin{array}{l}\text { High-income } \\
\text { countries }\end{array}$ & $\begin{array}{l}\text { Review of cancer care } \\
\text { delivery }\end{array}$ & $\begin{array}{l}\text { - Clinicians require analytic and clinical validity before testing } \\
\text { - Coverage with evidence development is an opportunity to generate data } \\
\text { - Alternative business models to be developed and encouraged }\end{array}$ & $\checkmark$ & & \\
\hline $\begin{array}{l}\text { Terkola et al. } \\
\text { (2017) }\end{array}$ & & Commentary & $\begin{array}{l}\text { - Lack of real-world data regarding costs and health outcomes } \\
\text { - No study confronting clinical trial and real-world data } \\
\text { - International coordination between regulators to establish standards }\end{array}$ & $\checkmark$ & & \\
\hline $\begin{array}{l}\text { Thomas et al. } \\
\text { (2010) }\end{array}$ & US & Industry perspective & $\begin{array}{l}\text { - Need for reimbursement that fosters evidence development } \\
\text { - Reimbursement systems should develop clearer standards } \\
\text { - Regulatory process has to integrate CDx in the appraisal of the drug }\end{array}$ & $\checkmark$ & $\checkmark$ & $\checkmark$ \\
\hline $\begin{array}{l}\text { Towse and } \\
\text { Garrison (2013) }\end{array}$ & & Commentary & $\begin{array}{l}\text { - Collaboration between stakeholders needed to increase evidence creation } \\
\text { - CED for realistic expectations for evidence standards } \\
\text { - Public investment along with manufacturers and payers to generate data }\end{array}$ & $\checkmark$ & & \\
\hline $\begin{array}{l}\text { Trosman et al. } \\
\text { (2010) }\end{array}$ & US & Interviews $(N=7)$ & $\begin{array}{l}\text { - Heterogeneity in clinical evidence perception among payers } \\
\text { - Clinical effectiveness is a paramount factor in coverage decision for all payers } \\
\text { - Approach to consider both clinical evidence and health care system factors }\end{array}$ & & $\checkmark$ & $\checkmark$ \\
\hline $\begin{array}{l}\text { Trosman et al. } \\
\text { (2011) }\end{array}$ & US & $\begin{array}{l}\text { Literature review and } \\
\text { interviews }(N=11)\end{array}$ & $\begin{array}{l}\text { - Payers use HTA more extensively for PM than for other technologies } \\
\text { - Limited relevance if HTA unavailable and insufficient nonclinical factors } \\
\text { - HTA organizations to improve their relevance to payers and clinicians }\end{array}$ & & $\checkmark$ & \\
\hline $\begin{array}{l}\text { Trosman et al. } \\
\text { (2015) }\end{array}$ & US & $\begin{array}{l}\text { Interviews }(N=24 \\
\text { experts / payers })\end{array}$ & $\begin{array}{l}\text { - Next-generation tumor sequencing deemed experimental/investigational } \\
\text { - Efforts for evidence generation and incorporation into policies necessary } \\
\text { - Misalignment between evidentiary methods and payers' needs }\end{array}$ & & & $\checkmark$ \\
\hline $\begin{array}{l}\text { Trosman et al. } \\
\text { (2017) }\end{array}$ & US & $\begin{array}{l}\text { Interviews }(N=11 \\
\text { payers })\end{array}$ & $\begin{array}{l}\text { - Adjustment needed for PM to fit the coverage framework } \\
\text { - All interviewees find that lack of evidence is a coverage barrier } \\
\text { - Manufacturers need to include payers' evidentiary requirements }\end{array}$ & & & $\checkmark$ \\
\hline $\begin{array}{l}\text { Trosman et al. } \\
\text { (2018) }\end{array}$ & US & Review of coverage & $\begin{array}{l}\text { - Three approaches to adapt coverage framework for tumor sequencing } \\
\text { - RSA with manufacturer for performance data; CED for evidence generation } \\
\text { - Technology-specific coverage based on number of genes }\end{array}$ & & & $\checkmark$ \\
\hline
\end{tabular}


Table A1. Cont.

\begin{tabular}{|c|c|c|c|c|c|c|}
\hline Reference & Region & Methodology & Key Contents and Main Results & ER & GC & HS \\
\hline Vegter et al. (2008) & & $\begin{array}{l}\text { Literature review } \\
(N=20 \text { articles })\end{array}$ & $\begin{array}{l}\text { - Level of consistency among economic analyses generally poor } \\
\text { - Extensive sensitivity analyses and incorporate evidence-based data } \\
\text { - Checklist for performing pharmacoeconomic analysis }\end{array}$ & $\checkmark$ & & \\
\hline $\begin{array}{l}\text { Vozikis et al. } \\
(2016)\end{array}$ & EU & $\begin{array}{l}\text { Review of pricing and } \\
\text { reimbursement }\end{array}$ & $\begin{array}{l}\text { - Overview of basic principles guiding governance of genomic testing services } \\
\text { - Need for one single HTA agency for selection of priority areas } \\
\text { - Merge all the current reimbursement processes under one committee }\end{array}$ & $\checkmark$ & $\checkmark$ & \\
\hline
\end{tabular}

Note: $\mathbf{E R}=$ Economic relevance, GC = Governance challenges, $\mathbf{H S}=$ Implementation in the health care system. 


\section{References}

Akhmetov, Ildar, and Rostyslav V. Bubnov. 2017. Innovative payer engagement strategies: Will the convergence lead to better value creation in personalized medicine? EPMA Journal 8: 5-15. [CrossRef]

Amendola, Laura M., M. Ragan Hart, Robin L. Bennett, Martha Horike-Pyne, Michael Dorschner, Brian Shirts, and Gail P. Jarvik. 2019. Insurance coverage does not predict outcomes of genetic testing: The search for meaning in payer decisions for germline cancer tests. Journal of Genetic Counseling 28: 1208-13. [CrossRef]

Antonanzas, Fernando, Reyes Juárez-Castelló, Carmeloand Lorente, and Roberto Rodríguez-Ibeas. 2019. The use of risk-sharing contracts in healthcare: Theoretical and empirical assessments. PharmacoEconomics 37: 1469-83. [CrossRef]

Basu, Anirban. 2015. Financing cures in the United States. Expert Review of Pharmacoeconomics E Outcomes Research 15: 1-4. [CrossRef]

Boon, Wouter, Luis Martins, and Marc Koopmanschap. 2015. Governance of conditional reimbursement practices in the Netherlands. Health Policy 119: 180-85. [CrossRef] [PubMed]

Carrera, Pricivel, and Maarten J. IJzerman. 2016. Are current ICER thresholds outdated? Valuing medicines in the era of personalized healthcare. Expert Review of Pharmacoeconomics \& Outcomes Research 16: 435-37. [CrossRef]

Chalkidou, Kalipso, and Sir Michael Rawlins. 2011. Pharmacogenetics and cost-effectiveness analysis: A two-way street. Drug Discovery Today 16: 873-77. [CrossRef] [PubMed]

Cohen, J., A. Wilson, and K. Manzolillo. 2013. Clinical and economic challenges facing pharmacogenomics. Pharmacogenomics Journal 13: 378-88. [CrossRef]

Cohen, P. Joshua, and E. Abigail Felix. 2014. Personalized medicine's bottleneck: Diagnostic test evidence and reimbursement. Journal of Personalized Medicine 4: 163-75. [CrossRef] [PubMed]

Degtiar, Irina. 2017. A review of international coverage and pricing strategies for personalized medicine and orphan drugs. Health Policy 121: 1240-48. [CrossRef]

Deverka, Patricia A., T. Doksum, and R. J. Carlson. 2007. Integrating Molecular Medicine into the US Health-care System: Opportunities, Barriers, and Policy Challenges Clinical Pharmacology E Therapeutics 82: 427-34. [CrossRef]

Deverka, Patricia A., and Jennifer C. Dreyfus. 2014. Clinical integration of next generation sequencing: Coverage and reimbursement challenges. The Journal of Law, Medicine E Ethics 42: 22-41. [CrossRef]

Deverka, Patricia A. 2009. Pharmacogenomics, evidence, and the role of payers. Public Health Genomics 12: 149-57. [CrossRef] [PubMed]

Dunn, Jessilyn, Ryan Runge, and Michael Snyder. 2018. Wearables and the medical revolution. Personalized Medicine 15: 429-48. [CrossRef] [PubMed]

Faulkner, Eric, Leven Annemans, Lou Garrison, Mark Helfand, Anke-Peggy Holtorf, John Hornberger, Dyfrig Hughes, Tracy Li, Daniel Malone, Katherine Payne, and et al. 2012. Challenges in the development and reimbursement of personalized medicine-payer and manufacturer perspectives and implications for health economics and outcomes research: A report of the ispor personalized medicine special interest group. Value in Health 15: 1162-71. [CrossRef]

Faulkner, S. D., M. Lee, D. Qin, L. Morrell, E. Xoxi, A. Sammarco, S. Cammarata, P. Russo, L. Pani, and R. Barker. 2016. Pricing and reimbursement experiences and insights in the european union and the united states: Lessons learned to approach adaptive payer pathways. Clinical Pharmacology \& Therapeutics 100: 730-42. [CrossRef]

Ferrario, Alessandra, and Panos Kanavos. 2015. Dealing with uncertainty and high prices of new medicines: A comparative analysis of the use of managed entry agreements in Belgium, England, the Netherlands and Sweden. Social Science \& Medicine 124: 39-47. [CrossRef]

Fugel, Hans-Joerg, Mark Nuijten, and Maarten Postma. 2012. Stratified medicine and reimbursement issues. Frontiers in Pharmacology 3: 181. [CrossRef]

Garfield, Susan. 2011. Advancing Access to Personalized Medicine: A Comparative Assessment of European Reimbursement Systems. Technical Report. Washington, DC: Personalized Medicine Coalition.

Garrison, Louis P., and M.J. Finley Austin. 2006. Linking pharmacogenetics-based diagnostics and drugs for personalized medicine. Health Affairs 25: 1281-90. [CrossRef] 
Garrison, Louis P., and Adrian Towse. 2017. Value-based pricing and reimbursement in personalised healthcare: Introduction to the basic health economics. Journal of Personalized Medicine 7: 10. [CrossRef]

Garrison, Louis P., Adrian Towse, Andrew Briggs, Gerard de Pouvourville, Jens Grueger, Penny E. Mohr, J.L. (Hans) Severens, Paolo Siviero, and Miguel Sleeper. 2013. Performance-based risk-sharing arrangements-Good practices for design, implementation, and evaluation: Report of the ISPOR good practices for performance-based risk-sharing arrangements task force. Value in Health 16: 703-19. [CrossRef] [PubMed]

Graf, Michael D, Denise F Needham, Nicole Teed, and Trisha Brown. 2013. Genetic testing insurance coverage trends: A review of publicly available policies from the largest US payers. Personalized Medicine 10: 235-43. [CrossRef] [PubMed]

Hall, Peter S., and Christopher McCabe. 2013. What evidence is there for the reimbursement of personalised medicine? Pharmacoeconomics 31: 181-83. [CrossRef] [PubMed]

Hammond, Ray. 2020. The World In 2040-Future Health, Care E Well-Being. Available online: https://www. allianz-partners.com/en_US/press-and-media/reports/future-health-care-wellbeing.html (accessed on 15 October 2020).

Henry, JaWanna, Yuriy Pylypchuk, Talisha Searcy, and Vaishali Patel. 2016. Adoption of electronic health record systems among u.s. non-federal acute care hospitals: 2008-2015. ONC Data Brief 35, Office of the National Coordinator for Health Information Technology. Available online: https:/ dashboard.healthit. gov / evaluations / data-briefs / non-federal-acute-care-hospital-ehr-adoption-2008-2015.php (accessed on 15 October 2020).

Hresko, Andrew, and B. Susanne Haga. 2012. Insurance coverage policies for personalized medicine. Journal of Personalized Medicine 2: 201-16. [CrossRef] [PubMed]

Kanavos, Panos, and Aris Angelis. 2013. Multiple criteria decision analysis for valuebased assessment of new medical technologies: A conceptual framework. Technical Report. London School of Economics and Political Science. Available online: http:/ / eprints.lse.ac.uk/51211 (accessed on 15 October 2020).

Knowles, Lori, Westerly Luth, and Tania Bubela. 2017. Paving the road to personalized medicine: Recommendations on regulatory, intellectual property and reimbursement challenges. Journal of Law and the Biosciences 4: 453-506. [CrossRef] [PubMed]

Leopold, C., S. Vogler, C. Habl, A. K. Mantel-Teeuwisse, and J. Espin. 2013. Personalised medicine as a challenge for public pricing and reimbursement authorities-A survey among 27 European countries on the example of trastuzumab. Health Policy 113: 313-22. [CrossRef]

Lu, Christine Y., Stephanie Loomer, Rachel Ceccarelli, Kathleen M. Mazor, James Sabin, Ellen Wright Clayton, Geoffrey S. Ginsburg, and Ann Chen Wu. 2018. Insurance coverage policies for pharmacogenomic and multi-gene testing for cancer. Journal of Personalized Medicine 8: 19. [CrossRef]

Lu, Christine Y., Caitlin Lupton, Shana Rakowsky, Zaheer-Ud-Din Babar, Dennis Ross-Degnan, and Anita K. Wagner. 2015. Patient access schemes in Asia-pacific markets: Current experience and future potential. Journal of Pharmaceutical Policy and Practice 8: 6. [CrossRef]

Lu, Christine Y., Marc S. Williams, Geoffrey S. Ginsburg, Sengwee Toh, Jeff S. Brown, and Muin J. Khoury. 2018. A proposed approach to accelerate evidence generation for genomic-based technologies in the context of a learning health system. Genetics in Medicine 20: 390-96. [CrossRef]

Mattke, Soeren, Hangsheng Liu, Emily Hoch, and Andrew W Mulcahy. 2017. Avoiding the tragedy of the commons in health care: Policy options for covering high-cost cures. Rand Health Quarterly 6: 1.

McCabe, Christopher, Karl Claxton, and Anthony J. Culyer. 2008. The NICE cost-effectiveness threshold. PharmacoEconomics 26: 733-44. [CrossRef] [PubMed]

Meckley, Lisa M., and Peter J. Neumann. 2010. Personalized medicine: Factors influencing reimbursement. Health Policy 94: 91-100. [CrossRef]

Merlin, Tracy, Claude Farah, Camille Schubert, Andrew Mitchell, Janet E. Hiller, and Philip Ryan. 2013. Assessing personalized medicines in Australia: A national framework for reviewing codependent technologies. Medical Decision Making 33: 333-42. [CrossRef] [PubMed]

Messner, Donna A., Jennifer Al Naber, Pei Koay, Robert Cook-Deegan, Mary Majumder, Gail Javitt, Patricia Deverka, Rachel Dvoskin, Juli Bollinger, Margaret Curnutte, and et al. 2016. Barriers to clinical adoption of next generation sequencing: Perspectives of a policy Delphi panel. Applied and Translational Genomics 10: 19-24. [CrossRef] 
Miller, Iain, Joanna Ashton-Chess, Herman Spolders, Vincent Fert, Joseph Ferrara, Werner Kroll, Jon Askaa, Patrick Larcier, Patrick F. Terry, Anne Bruinvels, and et al. 2011. Market access challenges in the EU for high medical value diagnostic tests. Personalized Medicine 8: 137-48. [CrossRef] [PubMed]

Moher, David, Larissa Shamseer, Mike Clarke, Davina Ghersi, Alessandro Liberati, Mark Petticrew, Paul Shekelle, Lesley A. Stewart, and PRISMA-P Group. 2015. Preferred reporting items for systematic review and meta-analysis protocols (PRISMA-P) 2015 statement. Systematic Reviews 4: 1. [CrossRef]

National Human Genome Research Institute. 2020. DNA Sequencing Costs: Data. Available online: https: / / www.genome.gov/about-genomics/fact-sheets/DNA-Sequencing-Costs-Data (accessed on 15 October 2020).

Orofino, Javier, Javier Soto, Miguel A. Casado, and Itziar Oyagüez. 2010. Global spending on orphan drugs in France, Germany, the UK, Italy and Spain during 2007. Applied Health Economics and Health Policy 8: 301-15. [CrossRef]

O'Sullivan, Brian P., David M. Orenstein, and Carlos E. Milla. 2013. Pricing for orphan drugs: Will the market bear what society cannot? JAMA 310: 1343-44. [CrossRef]

Pauly, Mark V. 2019. Cost sharing in insurance coverage for precision medicine. In Economic Dimensions of Personalized and Precision Medicine. Chicago: University of Chicago Press, Chapter 10, pp. 159-84. [CrossRef]

Payne, Katherine, and Lieven Annemans. 2013. Reflections on market access for personalized medicine: Recommendations for Europe. Value in Health 16: S32-S38. [CrossRef]

Phillips, Kathryn A., Patricia A. Deverka, Julia R. Trosman, Michael P. Douglas, James D. Chambers, Christine B. Weldon, and Andrew P. Dervan. 2017. Payer coverage policies for multigene tests. Nature Biotechnology 35: 614-17. [CrossRef]

Pokorska-Bocci, Anna, Alison Stewart, Gurdeep S Sagoo, Alison Hall, Mark Kroese, and Hilary Burton. 2014. 'Personalized medicine': What's in a name? Personalized Medicine 11: 197-210. [CrossRef]

Ramsey, Scott D., David L. Veenstra, Louis P. Garrison, Rick Carlson, Paul Billings, Josh Carlson, and Sean D. Sullivan. 2006. Toward evidence-based assessment for coverage and reimbursement of laboratory-based diagnostic and genetic tests. The American Journal of Managed Care 12: 197-202. [PubMed]

Schey, Carina, Tsveta Milanova, and Adam Hutchings. 2011. Estimating the budget impact of orphan medicines in Europe: 2010-2020. Orphanet Journal of Rare Diseases 6: 62. [CrossRef] [PubMed]

Schwarzer, Ruth, Ursula Rochau, Kim Saverno, Beate Jahn, Bernhard Bornschein, Nikolai Muehlberger, Magdalena Flatscher-Thoeni, Petra Schnell-Inderst, Gaby Sroczynski, Martina Lackner, and et al. 2015. Systematic overview of cost-effectiveness thresholds in ten countries across four continents. Journal of Comparative Effectiveness Research 4: 485-504. [CrossRef] [PubMed]

Simeonidis, Stavros, Stefania Koutsilieri, Athanassios Vozikis, David N. Cooper, Christina Mitropoulou, and George P. Patrinos. 2019. Application of economic evaluation to assess feasibility for reimbursement of genomic testing as part of personalized medicine interventions. Frontiers in Pharmacology 10: 830. [CrossRef] [PubMed]

Spear, Brian B, Margo Heath-Chiozzi, and Jeffrey Huff. 2001. Clinical application of pharmacogenetics. Trends in Molecular Medicine 7: 201-4. [CrossRef]

Sullivan, Richard, Jeffrey Peppercorn, Karol Sikora, John Zalcberg, Neal J Meropol, Eitan Amir, David Khayat, Peter Boyle, Philippe Autier, Ian F Tannock, and et al. 2011. Delivering affordable cancer care in high-income countries. The Lancet Oncology 12: 933-80. [CrossRef]

Sultana, Janet, Paola Cutroneo, and Gianluca Trifirò. 2013. Clinical and economic burden of adverse drug reactions. Journal of Pharmacology \& Pharmacotherapeutics 4: S73-S77. [CrossRef]

Terkola, Robert, Fernando Antoñanzas, and Maarten Postma. 2017. Economic evaluation of personalized medicine: A call for real-world data. The European Journal of Health Economics 18: 1065-67. [CrossRef]

Thomas, Adrian, Audrey Phillips, Robert Donnelly, and Catherine Tak Piech. 2010. Comparative effectiveness, personalized medicine and innovation. PharmacoEconomics 28: 923-30. [CrossRef]

Towse, Adrian, and Louis P. Garrison. 2013. Economic incentives for evidence generation: Promoting an efficient path to personalized medicine. Value in Health 16: S39-S43. [CrossRef]

Trosman, Julia R., Stephanie L. Van Bebber, and Kathryn A. Phillips. 2010. Coverage policy development for personalized medicine: Private payer perspectives on developing policy for the 21-gene assay. Journal of Oncology Practice 6: 238-42. [CrossRef] 
Trosman, Julia R., Stephanie L. Van Bebber, and Kathryn A. Phillips. 2011. Health technology assessment and private payers' coverage of personalized medicine. Journal of Oncology Practice 7: 18s-24s. [CrossRef] [PubMed]

Trosman, Julia R., Christine B. Weldon, Michael P. Douglas, Allison W. Kurian, R. Kate Kelley, Patricia A. Deverka, and Kathryn A. Phillips. 2017. Payer coverage for hereditary cancer panels: Barriers, opportunities, and implications for the precision medicine initiative. Journal of the National Comprehensive Cancer Network 15: 219-28. [CrossRef] [PubMed]

Trosman, Julia R., Christine B. Weldon, William J. Gradishar, Al B. Benson, Massimo Cristofanilli, Allison W. Kurian, James M. Ford, Alan Balch, John Watkins, and Kathryn A. Phillips. 2018. From the past to the present: Insurer coverage frameworks for next-generation tumor sequencing. Value in Health 21: 1062-68. [CrossRef] [PubMed]

Trosman, Julia R., Christine B. Weldon, R. Kate Kelley, and Kathryn A. Phillips. 2015. Challenges of coverage policy development for next-generation tumor sequencing panels: Experts and payers weigh in. Journal of the National Comprehensive Cancer Network 13: 311-18. [CrossRef]

Vegter, Stefan, Cornelis Boersma, Mark Rozenbaum, Bob Wilffert, GerJan Navis, and Maarten J. Postma. 2008. Pharmacoeconomic evaluations of pharmacogenetic and genomic screening programmes. PharmacoEconomics 26: 569-87. [CrossRef]

Vozikis, Athanassios, David N. Cooper, Christina Mitropoulouc, Manousos E. Kambouris, Angela Brand, Vita Dolzan, Paolo Fortina, Federico Innocenti, Ming Ta Michael Lee, Lada Leyens, and et al. 2016. Test pricing and reimbursement in genomic medicine: Towards a general strategy. Public Health Genomics 19: 352-63. [CrossRef]

Publisher's Note: MDPI stays neutral with regard to jurisdictional claims in published maps and institutional affiliations.

(c) 2020 by the authors. Licensee MDPI, Basel, Switzerland. This article is an open access article distributed under the terms and conditions of the Creative Commons Attribution (CC BY) license (http://creativecommons.org/licenses/by/4.0/). 